\title{
China's Nonferrous Metals Industry and Implications for Korea-China FTA Negotiations
}

\author{
Jung-O Ko and Jung-ran Cho*
}

\begin{abstract}
Korea and China have promoted a bilateral FTA since 2005 to upgrade their economic relationships. If the Korea-China FTA is concluded, then trade between the two countries is likely to involve substantial changes both quantitatively and qualitatively. Offer lists submitted by Korea include steel, petrochemicals and machinery and those by China include some agricultural and marine products as well as nonferrous metals. Korea's interest in the Korea-China FTA has focused mainly on damage to the agricultural sector and there have been a lot of studies on the effects of the FTA on Korean agricultural sector. However, little is known about why China includes the nonferrous metals industry for early voluntary liberalization and its implications for the domestic economy. Nonferrous metals industry is one of China's national strategic sectors and has a large supply excess in the country. This study targets the survey of Chinese nonferrous metals industry and trade structure and considers the problem of nonferrous metals in the context of negotiations for the Korea-China FTA and its implications for a higher-quality Korea-China FTA.
\end{abstract}

Keywords: Nonferrous Metal, Korea-China FTA, State-Owned Enterprise

JEL Classification: F13, F14, F41

\footnotetext{
* Research Professor, JRI, Inha University

This work was supported by the National Research Foundation of Korea Grant funded by The Korean Government (NRF-2011-413-B00008) and INHA University
} 


\section{Background}

The eighth round of negotiations for the Korea-China FTA, that is, the first round of negotiations in the second phase of the FTA, took place in Song-do, Inchon, in the fourth week of November ${ }^{1}$ and the two countries exchanged concession offers of goods for the first time. As concession offers include coverage of commodity by FTA members and tariff elimination schedules by commodity, discussions about opening the market are based on these offers. Tariff concessions for goods represent an area of serious concern in FTA negotiations and the successful conclusion of FTA negotiations involving developing countries generally depends on whether an agreement can be reached on the tariff liberalization of goods. In the case of the Korea-China FTA, an agreement on a $90 \%(85 \%)$ liberalization ratio of tariffs for goods based on the number of items (based on the import amount) between Korea and China is required.

According to the first-phase agreement between Korea and China, concession offers have been submitted mainly for general items (tariffs to be eliminated in 10 years) and sensitive items (liberalized in 10 20 years) except for very sensitive ones (exceptions from the tariff elimination or liberalization schedule for longer than 20 years). Concession items submitted by Korea include steel, petrochemicals and machinery, whereas those for China include some agricultural and marine products and nonferrous metals. The two countries are expected to exchange a list of very sensitive items during the ninth round of negotiations in China in January 2014.

Korea's interest in the Korea-China FTA has focused mainly on damage to the agricultural sector and therefore little is known about why China includes the nonferrous metals industry for early voluntary liberalization and its implications for the domestic economy. In particular, China's nonferrous metals industry is not a well-researched industry. In this regard, this study examines the market opening of the nonferrous metals industry and negotiation countermeasures in the context of the Korea-China FTA through a two-part research study. The first study (this paper) focuses on the analysis of China's nonferrous metals industry and considers some expected problems and major negotiation issues facing the Korea-China FTA in terms of the nonferrous metals industry. The second study (to be published later) will examine this topic in a more precise fashion.

The rest of this paper is organized as follows: Sections 2 and 3 describe the trends in China's nonferrous metals industry and the current state of its exports and imports, respectively. Section 4 analyzes the issues in negotiations for nonferrous metals in the

1) China and Korea have agreed to a two-phase negotiation format for their bilateral FTA. Here the first phase covers the sectors to be liberalized and the second one addresses additional negotiations based on the first one. 
Korea-China FTA in the context of subsidies for state-owned enterprises and Section 5 discusses the implications for negotiations for nonferrous metals in the Korea-China FTA and concludes.

\section{Recent trends in nonferrous metals in China}

Nonferrous metals refer to all metals except for iron and this section analyzes the trends in the production and consumption of the top four nonferrous metals in China, including copper, aluminum, zinc, etc. In the last two decades, China has emerged as the world's "manufacturing plant," becoming the leader not only in terms of production but also in terms of the consumption of raw materials as a result of the rapid grow of its manufacturing sector. China ranks among the top in terms of the production and consumption of nonferrous metals after a steady increase and this has had decisive effects on world prices. In addition, the nonferrous metals industry is managed mostly by SOEs and thus can be considered to operate in a typical non-market economy because of huge state support provided every year.

\subsection{Overall status}

In 2012, Asia accounted for about $65 \%$ of the global consumption of nonferrous metals and China accounted for a vast majority (44\%). Asia also accounted for a major share of production (58\% for aluminum, $48 \%$ for copper and $61 \%$ for zinc) in the same year and China again accounted for a majority ( $29 \%$ to $44 \%$ ).

China consumed $10,240 \mathrm{k}$ tons of 10 major nonferrous metals in 2002, but this increased sharply to 40,880k tons in 2012. With China's rapid urbanization, its demand for raw materials, including nonferrous metals, is expected to increase sharply for a time being because infrastructure investment is steadily increasing. ${ }^{2}$ ) However, Chinese policy on the industry acceleration and the qualitative goals of economic growth may shrink its demand for nonferrous metals in the future.

As a result of the rapid growth of 10 major nonferrous metals during the "10.5 Plan Period" (2001 2005), when the sophistication of the industry is driven in earnest, China emerged not only as the world's biggest producer of nonferrous metals but also as its biggest consumer. However, the global financial crisis in 2008 sharply reduced production

2) Interview by Zhaoyong (2013), China MINMETAL Vice President at http://finance.chinanews.com/ny/2013/06-26/4970266. 
amounts of nonferrous metals in China in 2008 and 2009, which substantial recovery seen as a result of the country's expansionary policy in 2010. In 2011, the growth rate of the global economy plummeted again, but since then, China's production of nonferrous metals has increased steadily, although the Chinese government has enforced a retrenchment policy as a result of the European financial crisis.

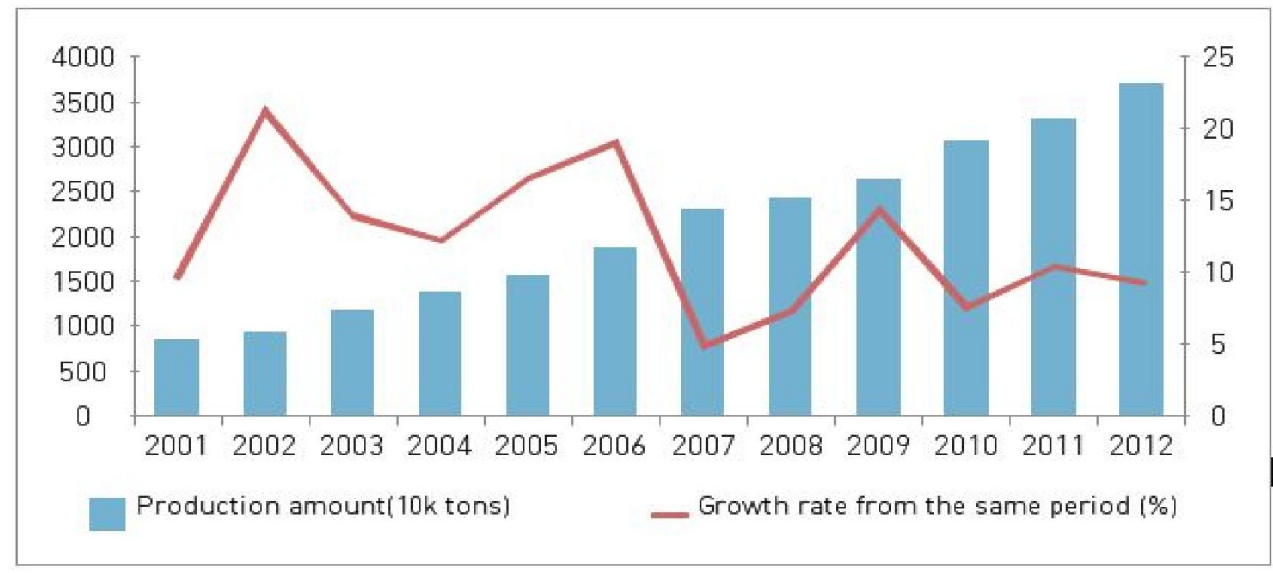

Source: The China Nonferrous Metals Industry Association (2009) "New China Nonferrous Metals Industry for 60years"ZhongNan University Press p. 452 470

Figure. 1

Production amounts and growth rates of 10 major nonferrous metals

The production of 10 major nonferrous metals in China (36,910k tons) increased by $9.3 \%$ from the same period a year earlier. Although the growth rate of other nonferrous metals declined, the production of aluminum increased sharply in conjunction with an expansion of the production capabilities in the western region, including Xinjiang. The production amounts of copper and aluminum were $1,169 \mathrm{k}$ tons and $30,740 \mathrm{k}$ tons respectively in 2012, reflecting $11 \%$ and $15.9 \%$ increases from 2011 . In addition, the total production of nickel in 2012 was $220 \mathrm{k}$ tons, a 16.5\% increase from 2011 and the production of 6 types of concentrated metals (copper, lead, zinc, nickel, tin and antimony) was $9680 \mathrm{k}$ tons, a $17.4 \%$ increase from 2011.

Although the revenue of a total of 8,057 firms in in the nonferrous metals industry (excluding gold and rare earth) over a certain size was RMB 4,137 billion in 2012, reflecting a $15.1 \%$ increase from 2011, the real profit was RMB 155.8 billion, an $8.9 \%$ decrease. 
In addition, the profit of the nonferrous metals industry and that of the smelting industry were RMB 41.1 billion and RMB 39.3 billion in 2011, reflecting 5.1\% and $34 \%$ decreases from 2011, respectively. The rolling of nonferrous metals generated a profit of RMB 66.6 billion in 2011, reflecting a 12.9\% increase from 2011 and there was some increase in the profitability of copper and aluminum.

\subsection{Industry trends in major nonferrous metals in China}

\section{Copper}

China is the world's largest producer and consumer of refined copper. Copper demand increased sharply as a result of the country's rapid growth from 2003 to 2012 and China's consumption of copper increased by about $5,000 \mathrm{k}$ tons during this period. China's production also increased from $1,780 \mathrm{k}$ tons in 2003 to $58010 \mathrm{~K}$ tons in 2012 , reflecting an average annual growth rate of $14 \%$. In fact, although China's copper consumption and production have increased sharply in recent years, 2012. China's total copper reserve has remained at about $26,000 \mathrm{k}$ tons, accounting for $5.3 \%$ of the world's total reserve. Insufficient copper resources have depended on imports domestically as a result of a few rich ores and many poor ones and foreign dependence reached $80 \%$ in 2012 . As a result, Korea recorded a trade surplus with China in 2012.

(Unit: 10K tons)

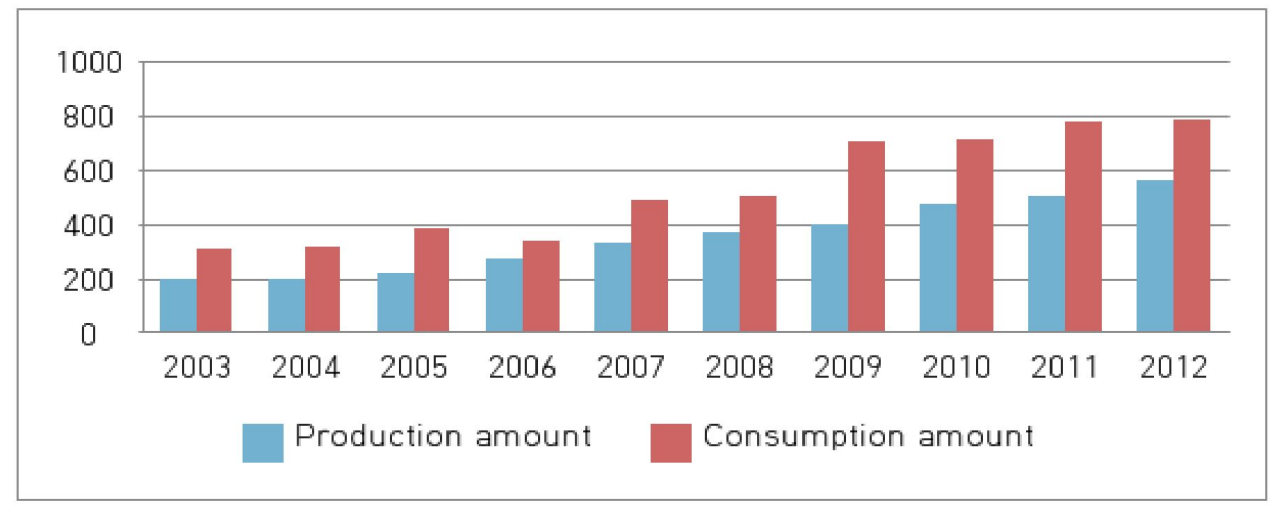

Source: Data taken from the China Nonferrous Metals Industry Association and the KIEP Korea-China Economic Form (2006).

Figure 2.

Copper production and consumption in China 


\section{Aluminum}

China is the world's largest producer and consumer of aluminum. With the rapid development of China from its urbanization and industrialization, aluminum has been consumed rapidly in several fields such as construction and transportation. The world's aluminum consumption increased from 299,610k tons in 2004 to 423,910k tons in 2011, reflecting an annual growth of 5.1\%. After a gradual increase, China's aluminum demand increased sharply from 143,910k tons in 2009 to $157,410 \mathrm{k}$ tons in 2010 and then to $180,610 \mathrm{k}$ tons in 2011 , a $14.7 \%$ increase. 3 )

(Unit: 10K tons)

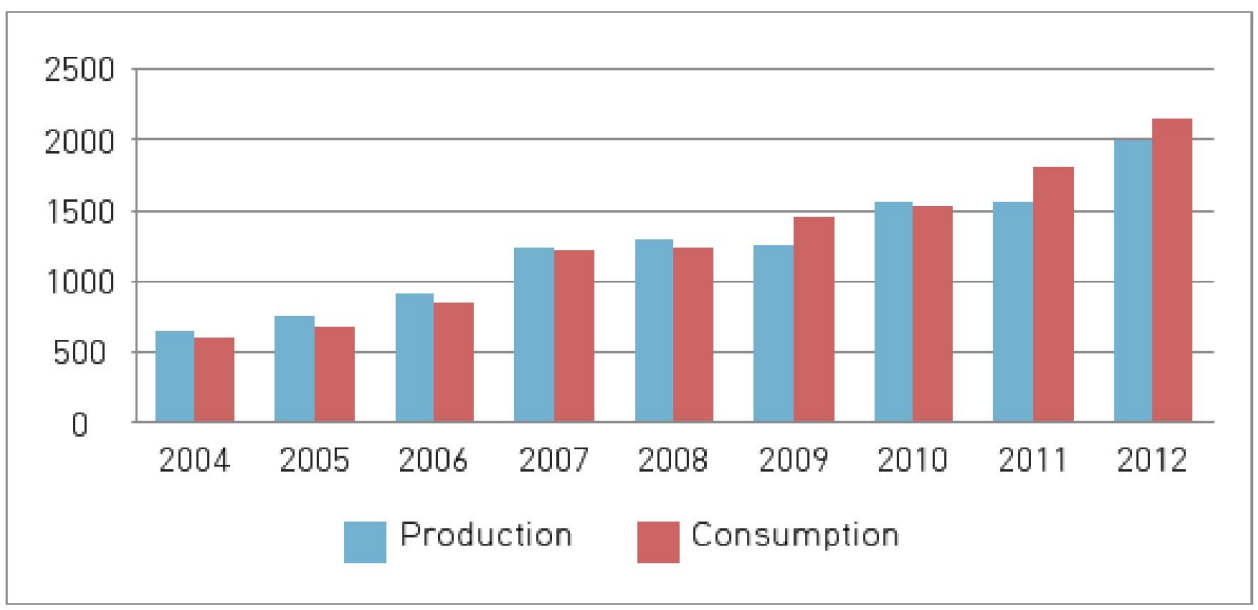

Source: Data taken from the China Nonferrous Metals Industry Association and the KIEP Korea-China Economic Form (2006).

\section{Figure 3.}

Aluminum production and consumption in China

China's aluminum consumption also increased from 58,000k tons in 2004 to $198,810 \mathrm{k}$ tons in 2012, reflecting an average annual growth rate of $17.6 \%$, which was much higher than that for the world. The steady increase in China's aluminum consumption, despite a decline in the country's real estate investment, can be attributed to the railroad, automobile and electric power industries. That is, heavy copper wires are substituted by light aluminum wires, despite their highly efficient electrical conduction. China's aluminum production

3) Credit Suisse (2012), "Chinese Aluminum Production: Resilient \& Adapting" at http://www.credit-suisse.com/researchandanalytics. 
increased sharply from $65,410 \mathrm{k}$ tons in 2004 to $215,010 \mathrm{k}$ tons in 2012 , reflecting an annual increase of $14.8 \%$.

The aluminum industry, together with the real estate, automobile and electronics industries, shrank as a result of the global financial crisis in 2008, but China's aluminum industry showed excess supply because of the rapid expansion of its production capacity in 2008. In 2008, aluminum was overproduced by $11,210 \mathrm{k}$ tons at the global level and excess supply reached $2.8 \%$ of total demand. This problem of aluminum overproduction was serious at the global level in 2009, reflecting a total increase of 2,440k tons and excess supply accounted for $7.1 \%$ of total demand. The problem of aluminum overproduction slowly dissipated in 2010 as a result of improvements in the global economy and aluminum production increased to $22,310 \mathrm{k}$ tons in 2011 after a decrease in excess supply by $14,310 \mathrm{k}$ tons. China's aluminum production accounted for about $44 \%-50 \%$ of total global production and China's aluminum production showed a continuously increasing trend, although its aluminum production was severely affected by excess supply and price declines.

\section{Lead}

China's lead consumption in 2011 is $4,660 \mathrm{k}$ tons, accounting for $47 \%$ of total global consumption $4,660 \mathrm{k}$ tons and the country maintains its status as the world's largest lead consumer for 11 straight years. Despite the European financial crisis, China's lead consumption increased steadily and played a major role as a driver of the global lead market. However, lead consumption was somewhat limited as a result of a slowdown in the growth rate of domestic car sales in China. Lead production increased to 46,510k tons in 2012, reflecting a 12\% increase from 2012. However, lead supply is expected to be stable because the scale of profits can be realized even when actual profits decline from decreases in the lead price. 
(Unit: 10K tons)

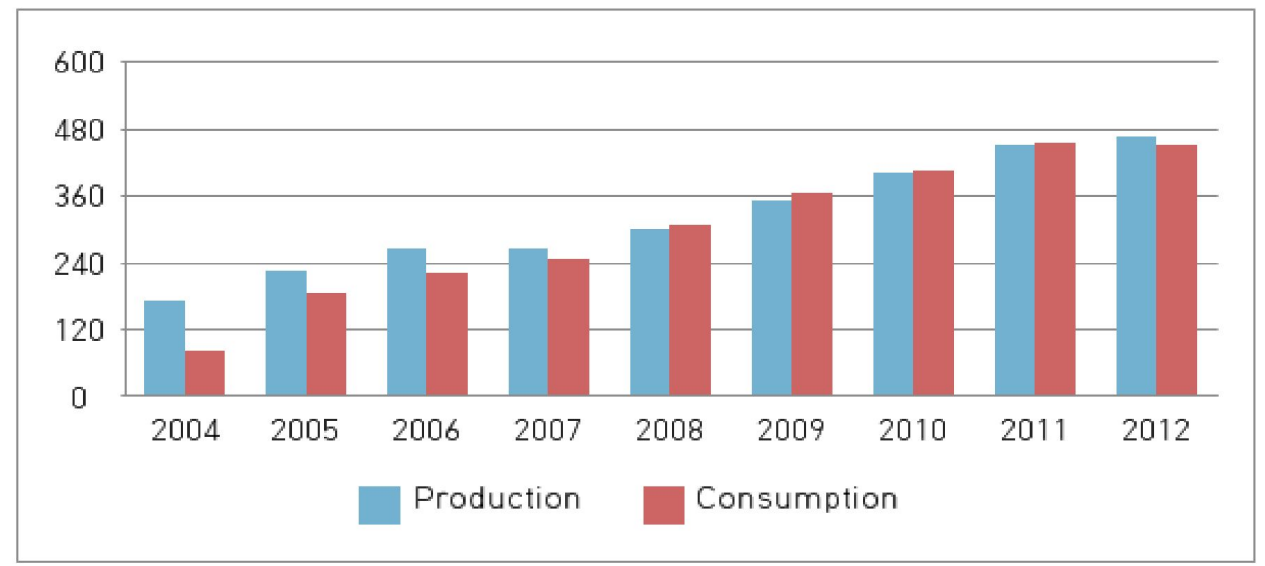

Source: Data taken from the China Nonferrous Metals Industry Association and the KIEP Korea-China Economic Form (2006)

\section{Figure 4.}

Lead production and consumption in China

\section{Zinc}

The average annual growth rate of zinc production in China from 2004 to 2011 was $10.4 \%$ and the average growth rate of global zinc consumption was $2.6 \%$. After the global financial crisis in 2008, zinc consumption declined, but domestic sales of zinc increased because of the expansion of domestic demand in 2010. Therefore, $20 \%$ of all home appliances were overproduced and vehicle production also increased by $30 \%$ during the same period. China's zinc consumption reached 53,310k tons in 2011, reflecting an $8 \%$ increase from 2010. 
(Unit: 10K tons)

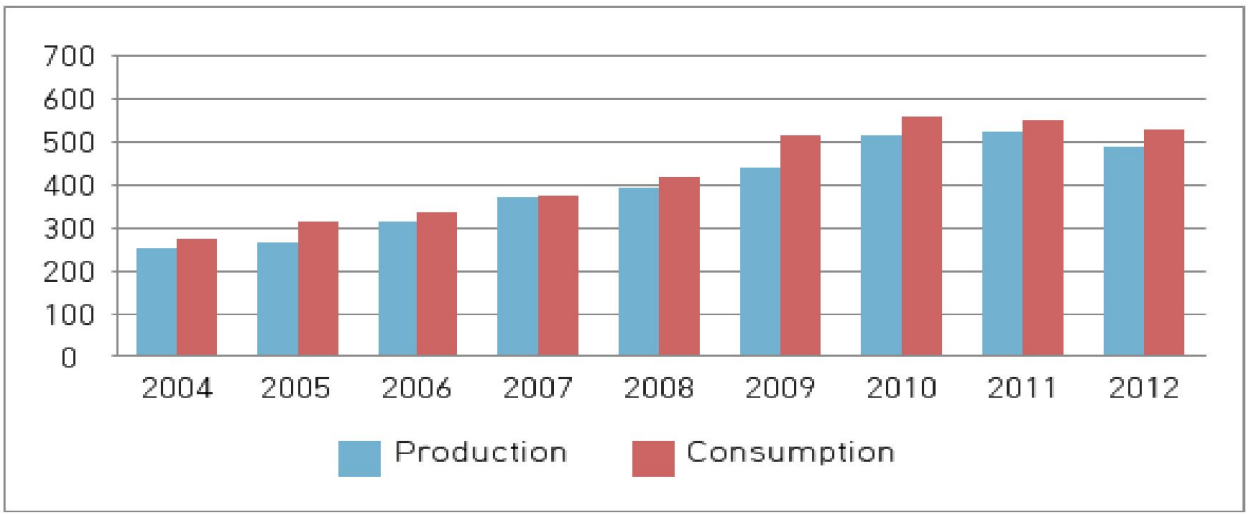

Source: Data taken from various sources: The China Nonferrous Metals industry Association : http://www.chinania.org.cn/html/hangyetongji/tongji/2013/0130/11201.html2001- China zinc production Report 2010:http://www.askci.com/data/viewdata187139.html. China zinc production Report 2011: http://www.100ppi.com/news/detail-20120214- 139846.html. China zinc production of monthly statistics2012: http://info.1688.com/detail/1115402750.html. Linrumei(2006), "Current situation and Prospect of nonferrous metal mineral resources development Chinese", Chinese Metal Bulletin, Vol.35

\section{Figure 5.}

Zinc production and consumption in China

However, zinc consumption also decreased by $2.1 \%$ as a result of decreases in the consumption of vehicles and home appliances as well as in real estate investment in 2011. However, China's long-term demand for white goods increased and decreases in zinc demand were not affected because of basic construction from urbanization. Global zinc production increased from 103,910k tons in 2004 to $130,910 \mathrm{k}$ tons in 2011, reflecting an average annual growth rate of $3.4 \%$. China's zinc production increased from $25,310 \mathrm{k}$ tons to $52,210 \mathrm{k}$ tons over the same period, reflecting an annual growth rate of $10.9 \%$, which was considerably higher than the global production average. China's zinc scale accounted for $38.4 \%$ of global zinc scale in 2012, showing a consistently increasing tread.

\section{Export and import trends in major nonferrous metal products in China}

China was a net importer of copper and zinc and a net exporter of aluminum and lead in 2010 and 2011. China's annual import of copper approached $3 \mathrm{M}$ tons, but its export of aluminum and lead was relatively modest. Nevertheless, it is difficult to comprehend why 
China has requested the opening of the Korean market after the nonferrous metals industry has been suggested as a priority industry for market liberalization in the Korea-China FTA. In addition, an antithetical policy in which the export of nonferrous metals is limited through the imposition of a value-added tax and the restructuring of the nonferrous metals industry is being evaluated. This suggests that China may be active in the Korea-China FTA negotiations to maintain the competiveness of its export prices through SOE subsidies and to secure markets that can be handled by any surplus supply when domestic demand is weak as a result of distinct characteristics of the equipment industry. Section 4 discusses the issues surrounding the Korea-China FTA, but the import and export trends in China's nonferrous metals industry are first explored.

\subsection{Overall trade trends in nonferrous metals}

China's export and import of nonferrous metals in 2012 totaled $\$ 166.431$ billion, reflecting a $3.76 \%$ increase from 2011. Its import totaled $\$ 114.911$ billion, reflecting a $1.98 \%$ decrease, whereas its export totaled $\$ 51.52$ billion, a $19.35 \%$ increase. The export of major nonferrous metal products in 2012 amounted to RMB 29.311 billion, reflecting a $13.08 \%$ decrease from 2011. With gold ornaments and components amounting to RMB 22.209 billion excluded, China's export and import of nonferrous metal products in 2012 showed slight increases, but the growth rate showed a $24.31 \%$ decrease from 2011 . Imports showed a minus growth rate and the growth rate of exports showed a $33.55 \%$ decline.

Imports of major smelting products of nonferrous metals including copper, aluminum and magnesium maintained an increasing trend and exports of copper and aluminum materials declined. As of the end of June 2012, imports of forged and rolled nickel amounted to 9,826 tons, reflecting a $29.26 \%$ decrease from 2011 and exports of the same amounted to 544 tons, reflecting a $71.21 \%$ decrease. More specifically, the amount of trade remained at about $40 \%$ of the production amount. The import weight increased sharply in the last decade, whereas the export weight in emerging economies was flat or declining. In particular, aluminum's domestic degree of self-support was relatively low in terms of its trade proportion in 2012 , but $42 \%$ of copper and $13 \%$ of zinc were net imports. 


\subsection{Export and import trends by item}

\section{Copper}

China has many copper manufacturers, but they are relatively small in terms of the scale of their equipment, falling behind global competitors and causing pollution. In addition, certain quantities of high-precision processed goods are imported every year, although the production capacity of products remains superfluous. Copper imports skyrocketed in the first half of 2009, but the speed of imports decreased gradually as a result of the recovery of copper production in the second half. After 2009, imports of refined copper declined every year and China's import of refined copper in 2010 amounted to $2,922 \mathrm{k}$ tons, reflecting an $8.26 \%$ decrease from 2009. China's import of refined copper in 2011 was 2,836k tons, reflecting a $2.96 \%$ decrease from 2010.

(Unit: 10K tons)

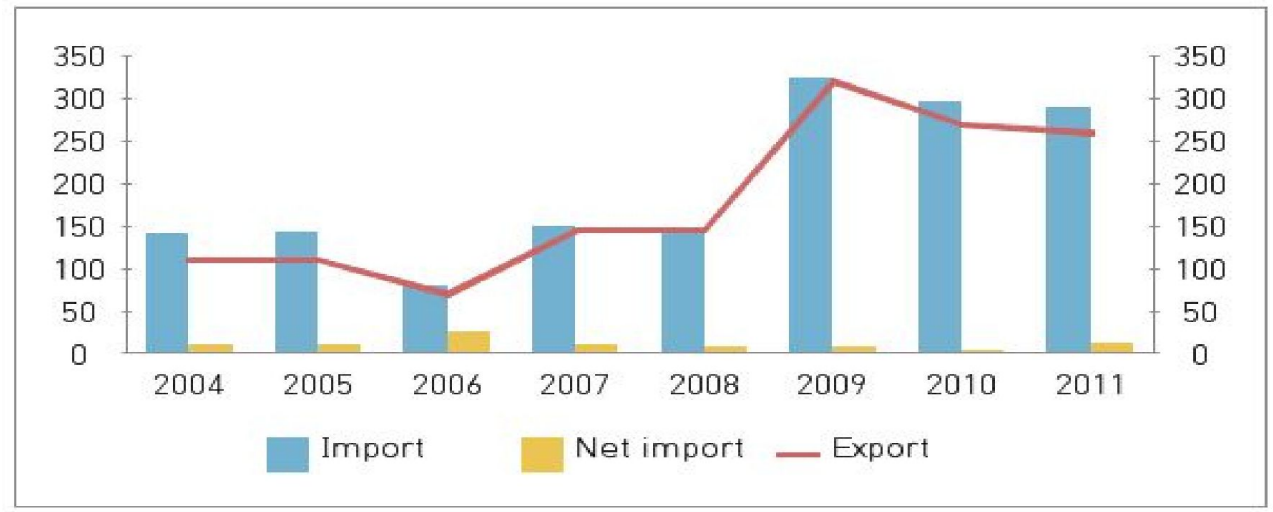

Source: The China Nonferrous Metals industry Association (2010), "Annual report on the import and export of china's cooper 2009", p. 5. Chinese industrial competitive intelligence network(2010), "Chinese Cooper industry research Report", p.11. Ruiyin(2012), "Ponderation over the Rapid Growth of China's export Trade", UBS Investment Research p.2-3

\section{Figure 6.}

Copper exports and imports of China from 2004 to 2011

\section{Aluminum}

After the global financial crisis, China's aluminum imports skyrocketed in 2009. China's total import in 2009 was 1,496.1k tons, reflecting an 11.3-fold increase from 2008. 
However, China aluminum imports amounted to 3,610k tons after 2010, reflecting a $79.03 \%$ decrease from 2009. Aluminum imports declined further to 330k tons in 2011, showing an $8.7 \%$ decrease. China's aluminum export declined sharply in 2009 and its total export amounted to $49.5 \mathrm{k}$ tons in 2009 , reflecting a $55.04 \%$ decrease from 2008. Aluminum exports increased to 7,510k tons in 2010, reflecting a 1.43-fold increase from 2009. China's aluminum export in 2011 increased slightly to $7,710 \mathrm{k}$ tons, showing a $1.0 \%$ increase from 2010. In sum, China's net import of aluminum in 2009 was 1,446.6k tons, showing an increase of $14,435.1 \mathrm{k}$ tons from 2008 , followed by speedy consumption. With the improvement in the global economy in 2010, China's net export reached 3,910k tons and its net export in 2011 reached 4,410k tons. However, because of the high domestic degree of self-support for China, the world's largest aluminum producer and consumer, its trade proportion was not very high.

(Unit: 10K tons)

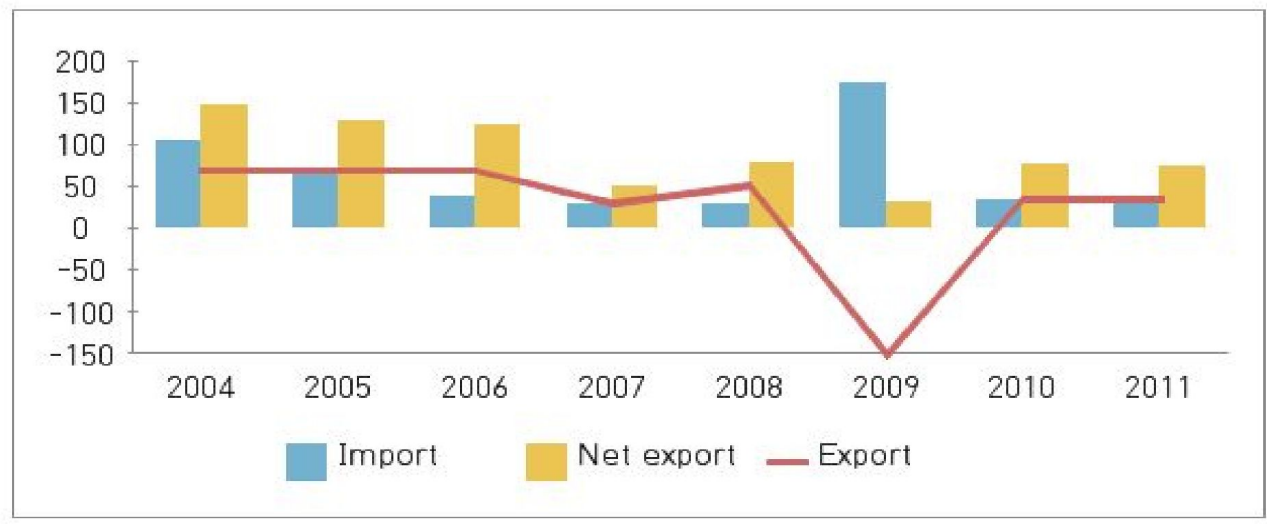

Source: YuanYuan (2011), "China aluminum products import and export trade review"

Figure 7.

Aluminum exports and imports of China from 2004 to 2012

\section{Lead}

China's lead imports declined sharply in 2010 and 2011 and decreased further because of high import costs from increases in the cost of foreign conversion, which was considerably lower than the domestic cost and because domestic smelting firms do not import pure lead. In addition, because China's smelting firms minimize their use of domestic lead, the country's lead imports in 2011 amounted to $24.9 \mathrm{k}$ tons, reflecting a $60 \%$ 
decrease from 2010. China's lead exports in 2011 amounted to $10.2 \mathrm{k}$ tons, reflecting a $60 \%$ decrease from 2009.

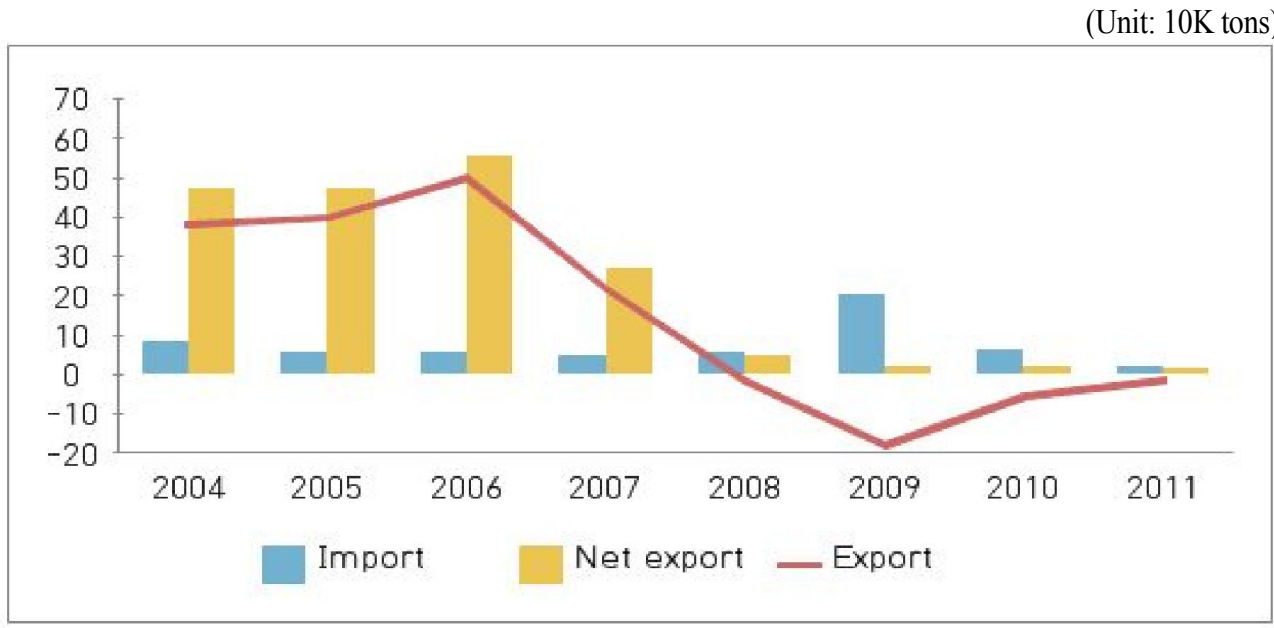

Source: Iiuliangxian · Yuzequan (2013),"The 2012 Report on the import and export analysis of Chinese tungsten products ", Chinese Tungsten Industry, p.12-17. Iiu liang xian (2011), "The 2010 Report on the import and export analysis of Chinese tungsten products", Chinese Tungsten Industry, p.5-7. Iiu liang xian (2010), "The 2009 Report on the import and export analysis of Chinese tungsten products", Chinese Tungsten Industry, p.8-10

\section{Figure 8.}

Lead exports and imports of China from 2004 to 2012

Zinc

China's zinc exports declined three years in a row. Zinc firms' trade volume declined because a $15 \%$ export tax has been imposed on zinc products with less than $99.99 \%$ purity at the beginning of June 2007. China's zinc exports in 2007 amounted to 280k tons, reflecting a 19\% decrease from 2006 and its exports in 2008 amounted to $70 \mathrm{k}$ tons, showing a sharp decrease of 74\% from 2007. China's zinc exports in 2010 amounted to $40 \mathrm{k}$ tons, showing a further decline. China's zinc exports and imports showed sharply declining three-year trends. 
(Unit: 10K tons)

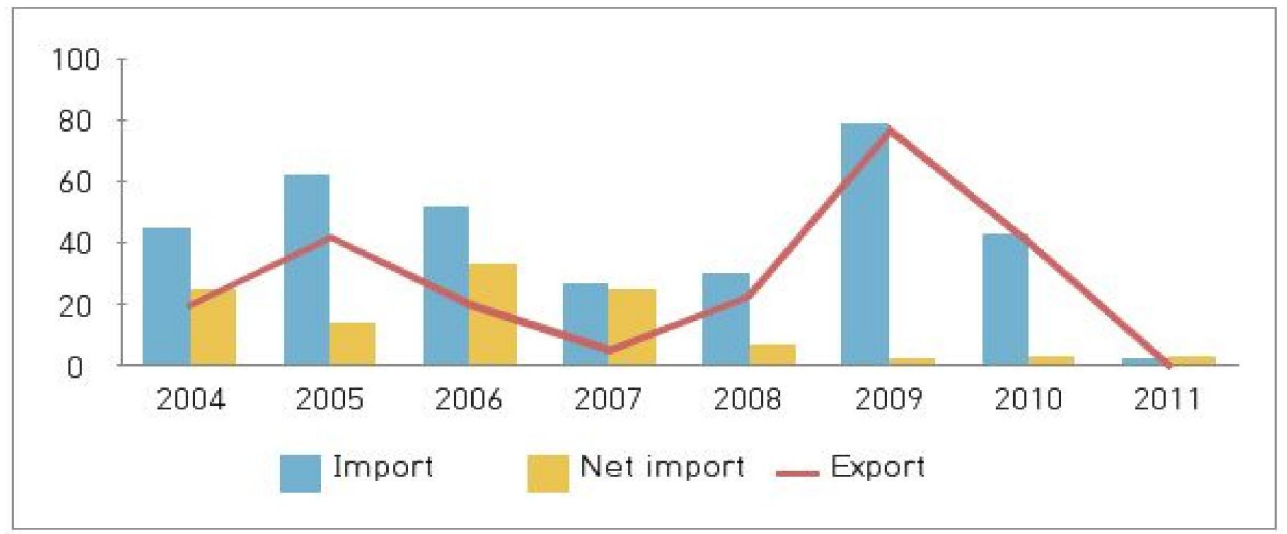

Source: China Customs Information Center(2012), Monitoring Report of China`s import and export of Zinc 2011". Fan $\operatorname{Li}(2012)$, "Analysis of factors which influence import and export of lead concentrate in china ", Modern Minin Vol.28,p.14-18

\section{Figure 9.}

Zinc exports and imports of China from 2004 to 2012

China's zinc industry showed strong growth in recent years and there was a substantial industry concentration. Inflation, the cost of labor and the increased cost of energy still occurs a structural contradiction in the zinc industry, although environment protection, energy savings and greenhouse gas reductions by firms show some progress. In addition, because of the polarization of the management environment, cost and labor management has weakened sharply, although there have been improvements in China's sales channels, warehouse and distribution capability, communications infrastructure and living conditions. China's "Nonferrous Metals Industry Adjustment and Promotion Plan," announced in May 2009, represents the country's strategy to improve its resource arrangement and management by accelerating the speed of mergers and acquisitions among the top 10 zinc firms and to lead the zinc industry toward a core industry with sufficient competitiveness. 


\section{Nonferrous metals in the Korea-China FTA}

\subsection{Nonferrous metals and the Korea-China FTA}

Because China is Korea's largest trading partner, it is crucial for Korea to have an FTA with China. According to a report by the Korea Institute for International Economic Policy, Korea's GDP and trade surplus are expected increase by 2.3\% (KRW 17, 900 billion) and $\$ 2.6$ billion, respectively, in the manufacturing sector through the Korea-China FTA. This is based on the assumption that exports of industrial products would increase as tariff benefits facilitate their price competitiveness in the Chinese market. In addition, domestic consumers can purchase Chinese goods at lower prices. The amount of trade between Korea and China exceeded \$200 billion for the first time in 2012 and has not only increased in size but also changed gradually and complementarily in structural aspects. Because China is Korea's largest trading partner and trade barriers are formidable, the FTA agreement might affect a lot.

However, it is expected that gains and losses from the Korea-China FTA may vary across firms and industries. By business type, vehicles, home appliances, steel and petrochemicals can gain a comparative advantage, whereas agricultural and fishery products, nonferrous metals and livestock may face some damage. In particular, increases in exports and production are expected from core firms with a clear comparative advantage, but other fields may be at a disadvantage relative to China. In particular, the nonferrous metals industry is concerned about facing damage domestically based on imports of Chinese products instead of gaining benefits through the FTA. With respect to weighted average tariff rates for the two countries by industry for three years from 2010 to 2012, Korea imposed a tariff of 4\%, an industry average, on Chinese products in 2012, whereas China imposed 3.2\%, although Chinese tariff rates varied over time. This reflects sharp decreases in China's tariff rates after its accession to the WTO. This takes place in nonferrous metals. Korea imposed a tariff of 5\% on Chinese nonferrous metals after 2012, whereas China maintained a 3.0\% tariff. 


\section{Table 1.}

A comparison of tariff rates between Korea and China by industry: 2010 and 2012

\begin{tabular}{|c|c|c|c|c|c|c|c|}
\hline & \multirow[b]{2}{*}{ Nonferrous metals } & \multicolumn{2}{|c|}{2010} & \multicolumn{2}{|c|}{2011} & \multicolumn{2}{|c|}{2012} \\
\hline & & $\begin{array}{c}\text { Nonferrous } \\
\text { metals }\end{array}$ & Total & $\begin{array}{c}\text { Nonferrous } \\
\text { metals }\end{array}$ & Total & $\begin{array}{c}\text { Nonferrous } \\
\text { metals }\end{array}$ & Total \\
\hline \multirow{5}{*}{$\begin{array}{l}\text { Korea's } \\
\text { tariff } \\
\text { rates for } \\
\text { China }\end{array}$} & Basic tariff rates & 5.9 & 9.0 & 5.8 & 9.0 & 5.8 & 9.2 \\
\hline & WTO MFN rates & 9.1 & 11.4 & 9.1 & 11.4 & 9.1 & 11.5 \\
\hline & $\begin{array}{l}\text { Import values for } \\
\text { China } \\
\text { (in million USD) }\end{array}$ & 1,413 & 71,561 & 2,135 & 86,426 & 1,549 & 80,768 \\
\hline & $\begin{array}{l}\text { Effective tariff rates } \\
\text { for China } \\
\text { (simple average, } \%)\end{array}$ & 5.6 & 7.5 & 5.5 & 7.5 & 5.5 & 7.8 \\
\hline & $\begin{array}{l}\text { Weighted average } \\
\text { tariff rates }(\%)\end{array}$ & 5.0 & 4.2 & 4.9 & 4.4 & 5.1 & 4.6 \\
\hline \multirow{4}{*}{$\begin{array}{l}\text { Chinese } \\
\text { tariff } \\
\text { rates for } \\
\text { Korea }\end{array}$} & $\begin{array}{c}\text { MFN tariff rates } \\
(\%)\end{array}$ & 5.9 & 9.1 & 6.2 & 9.6 & 5.8 & 9.2 \\
\hline & $\begin{array}{l}\text { Import values for } \\
\text { Korea } \\
\text { (in million USD) }\end{array}$ & 3,680 & 137,950 & 3,681 & 148,123 & 4,172 & 166,199 \\
\hline & $\begin{array}{c}\text { Effective tariff rates } \\
\text { for Korea } \\
\text { (simple average, } \% \text { ) }\end{array}$ & 5.8 & 8.5 & 6.1 & 9.0 & 5.7 & 8.6 \\
\hline & $\begin{array}{c}\text { Weighted average } \\
\text { tariff rates }(\%)\end{array}$ & 3.4 & 3.6 & 4.0 & 4.6 & 3.0 & 3.2 \\
\hline
\end{tabular}

Source: Compiled from Tariff Books of China and Korea

However, the issue of non-tariff barriers in China can be addressed through current FTA negotiations and sufficient benefits to compensate for tariffs are expected. In terms of China, Korea should reflect the discordance between its regulation and actual practice and a reasonable solution for conflicts in the FTA. Typical non-tariff barriers in China include transparency, export taxes, import restriction measures in a trade bloc, export license restriction, administration, judicial reviews, anti-dumping policies, subsidies, safeguards, trade-related investment measures, standard certification systems, intellectual property rights and governmental supply, among others. For nonferrous metals, it is necessary to 
check the transparency of SOEs, which represent one of the major features of China in the case of the Korea-China FTA.

\subsection{China's policy on nonferrous metals}

Funds for the technological development of nonferrous metals are being provided as part of a major policy initiative to promote China's nonferrous metals industry. According to the "Nonferrous Metals Industry Adjustment and Promotion Plan" for 2010, fund support is expected to be expanded for firms matched based on technologies for nonferrous metals, energy savings, circular flow of economic and pilot project of state-of-the-art technologies. In addition, the "Mining Resource Saving and Special Fund Management Plan for Integrated Utilization," jointly announced by China's Ministry of Finance and Ministry of Land and Resources, attempts to enhance the re-mining rate for mining resource for mining firms, mineral dressing recovery and integrated utilization and therefore, funds are supplied to firms for efficiency improvements through new technologies and changes in management methods for subsidies. The financial crisis has brought about efforts by the Chinese government to achieve price stability through government reserve and reduce financial burdens on firms producing nonferrous metals to prevent declines in prices of nonferrous metals.

The Chinese government is reported have reserves of nonferrous metals amounting to $590 \mathrm{k}$ tons of aluminum, 1,590k tons of zinc, 2,350k tons of copper, 30tons of indium and $5 \mathrm{k}$ tons of titanium for the nonferrous metals industry. In addition to these reserves, China operates a commercial reserve system for nonferrous metals by supplying special benefits such as bank loans and mortgages of local governments (including Yunnan, Henan, Guangxi and Jiangxi) and prices of major nonferrous metals increased by more than $30 \%$ in the national and commercial reserve systems in 2009. Further, institutional conveniences in decisions on prices of electricity thought direct negotiations between electric power firms and producers of nonferrous metals to reduce the burden from the production cost on these producers.

The Nonferrous Metals Industry Adjustment and Promotion Plan In 2009 also mentions the establishment of a pilot institution for reducing electricity prices for 15 firms producing electrolytic aluminum enterprises to be in compliance with the national industry policy and expand a list of pilot firms receiving special benefits in terms of electricity prices. In addition, a producer of copper was added in 2010 and the range of firms under the national industry policy is expected to be further expanded in the future. 


\section{Table 2.}

Mid- and long-term development plans (2006) and promotion plans (2009) for nonferrous metals

\begin{tabular}{|c|c|c|}
\hline Area & $\begin{array}{l}\text { Mid- and long-term development plans } \\
\text { for nonferrous metals (2006) }\end{array}$ & $\begin{array}{l}\text { Promotional plans for nonferrous metals } \\
\qquad \text { (2009) }\end{array}$ \\
\hline Policy focus & $\begin{array}{l}\text { - Focuses on the ceaseless deepening of } \\
\text { reform for science and technology } \\
\text { systems, the strengthening of science } \\
\text { and technology skills, the sharp } \\
\text { enhancement of technology equipment } \\
\text { and the acceleration of industry } \\
\text { sophistication. }\end{array}$ & $\begin{array}{l}\text { - Mentions the need for controlling the } \\
\text { total quantity, weeding out of old } \\
\text { production equipment, strengthening } \\
\text { of technology remodeling and } \\
\text { focusing on enterprise reconstruction. }\end{array}$ \\
\hline $\begin{array}{l}\text { Control of the } \\
\text { total quantity }\end{array}$ & $\begin{array}{l}\text { - Mentions the rationalization of } \\
\text { industry size is mentioned but does not } \\
\text { address specific goals for control of } \\
\text { the total quantity. }\end{array}$ & $\begin{array}{l}\text { - Stresses that production capacity } \\
\text { augmentation is strictly regulated } \\
\text { based on factors such as energy } \\
\text { availability, resources, the } \\
\text { environment and markets. }\end{array}$ \\
\hline $\begin{array}{l}\text { Weeding out } \\
\text { old } \\
\text { production } \\
\text { equipment }\end{array}$ & $\begin{array}{l}\text { - Emphasizes the modernization of } \\
\text { production technologies, the listing of } \\
\text { industry structure superiority and the } \\
\text { innovation of production equipment } \\
\text { but does not make specific comments } \\
\text { on weeding out of old production } \\
\text { equipment. }\end{array}$ & $\begin{array}{l}\text { - Annual copper: } 3,010 \mathrm{~K} \text { tons, lead: } \\
6,010 \mathrm{~K} \text { tons, zinc less than } 4,010 \mathrm{~K} \\
\text { tons. } \\
\text { - Electrolytic aluminum for heating } \\
\text { basin production equipment of less } \\
\text { than } 8,010 \mathrm{k} \text { tons as the weeding-out } \\
\text { standard. }\end{array}$ \\
\hline $\begin{array}{l}\text { Technology } \\
\text { remodeling }\end{array}$ & $\begin{array}{l}\text { - Focuses on increasing science and } \\
\text { technology investment and proposes } \\
\text { several science and technology } \\
\text { development plans, including the } \\
\text { strengthening of the platform for basic } \\
\text { science and technology environments. } \\
\text { - Highlights energy savings and } \\
\text { reductions in emissions of pollutants. } \\
\text { - electrolytic aluminum matching } \\
\text { current power consumption less than } \\
\text { 14,300 kwh/ton. } \\
\text { - Targets an increase in the sulfur } \\
\text { utilization rate to } 90 \% \text {. }\end{array}$ & $\begin{array}{l}\text { - Focuses on adherence to the mutual } \\
\text { connection between self-reliance } \\
\text { innovation and technology } \\
\text { remodeling. } \\
\text { - Emphasizes energy savings and } \\
\text { reductions in emissions of pollutant } \\
\text { emissions. } \\
\text { - Electrolytic aluminum matching } \\
\text { current power consumption less than } \\
12,500 \mathrm{kwh} / \text { ton. } \\
\text {-Targets an increase in the sulfur } \\
\text { utilization rate to } 97 \% \text {. }\end{array}$ \\
\hline $\begin{array}{c}\text { Enterprise } \\
\text { reconstruction }\end{array}$ & - No comment. & $\begin{array}{l}\text { - Mentions the formation of } 3 \sim 5 \\
\text { comprehensive company groups. }\end{array}$ \\
\hline
\end{tabular}




\begin{tabular}{c|l|l}
\hline \multirow{2}{*}{ Area } & $\begin{array}{c}\text { Mid- and long-term development plans } \\
\text { for nonferrous metals (2006) }\end{array}$ & \multicolumn{1}{c}{$\begin{array}{c}\text { Promotional plans for nonferrous metals } \\
\mathbf{( 2 0 0 9 )}\end{array}$} \\
\hline & & $\begin{array}{l}\text { - Highlights dramatic improvements in } \\
\text { the proportion of the top 10 domestic } \\
\text { firms in copper, aluminum, lead and } \\
\text { zinc in the total production volume } \\
\text { until 2011. }\end{array}$ \\
\hline $\begin{array}{c}\text { Tax revenue } \\
\text { policy for } \\
\text { export } \\
\text { promotion }\end{array}$ & - No comment. & $\begin{array}{l}\text { - Emphasizes appropriate increases in } \\
\text { export drawback rates for }\end{array}$ \\
\hline
\end{tabular}

Source: Moon et al. (2010) "A study on Chinese market analysis and expansion strategy of the component material industry"

The Chinese government has driven the restructuring of the overproduction sector. In May 2009, the Chinese government adjusted the proportion of the capital stock in firms with high energy consumption, including producers of electrolytic aluminum, from $35 \%$ to $40 \%$ by announcing the "Notification for Capital Stock Proportion Adjustment of Fixed Asset Investment Project" and weeding small producers of production equipment for electrolytic aluminum with less than $100 \mathrm{KA}$ and old lead smelting factories of sintering type out from the market by setting new objectives for 2009 to 2011 and strictly controlling their market entry through the mobilization of all kinds of administrative measures and the further strengthening of penalties through legal means. In April of 2012, the Chinese government announced the "Notification for Strengthening the Elimination of Old Production Capacities," which targets the expansion of structural regulation, the adjustment of the industrial structure and energy savings and is designed to drive intensive restructuring for nonferrous metals.

\subsection{China's SOEs and nonferrous metals}

Based on an amendment to the constitution by the 8th National People's Congress in 1993, the phrase "enterprises that the nation owns and manages at the same time" was revised to "enterprises that the nation owns and but whose management is carried out autonomously," and this definition can be easily used in the sense of the expansion of management sovereignty for simple enterprise development. China's SOEs are currently managed in the form of responsibility- and stock-based systems through the national 
property management sector. After the 1978 reform and opening, there has been a decline in the number of China's SOEs. However, as shown in Figure 10, there have been sharp increases in total profits and value-added taxes.

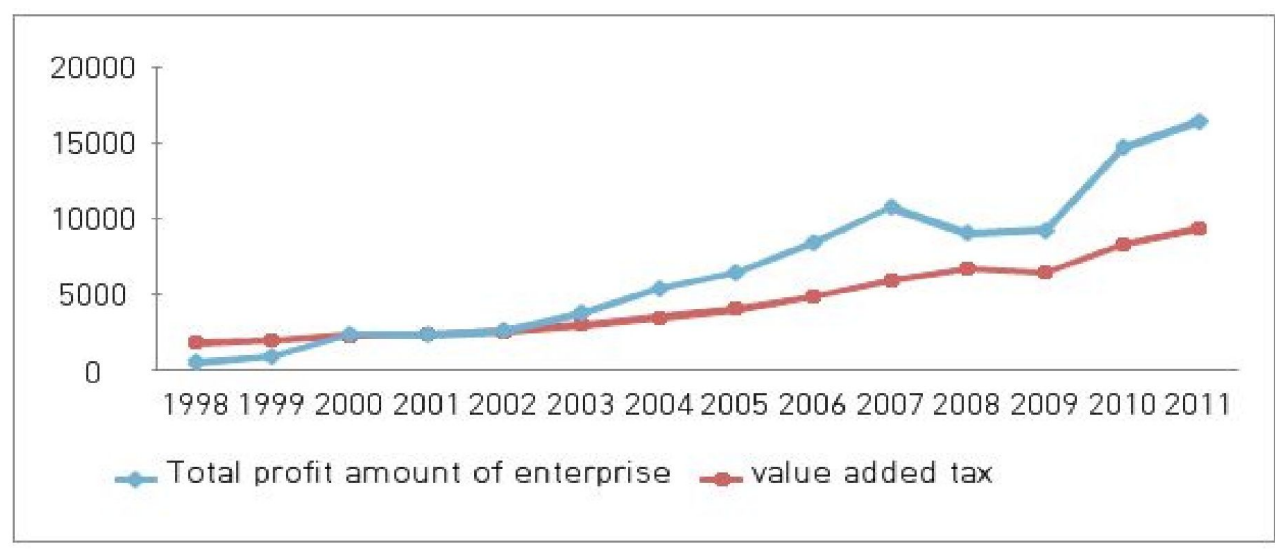

Source: The National Bureau of Statistics of China.

(http://www.stats.gov.cn/tjsj/ndsj/2012/html/N1408e.htm: 14-8 Main Indicators of State-owned and State-holding Industrial Enterprises by Region)

\section{Figure 10.}

Total profits and value-added tax of state-owned enterprises

Since the 11th Party Congress, SOEs have been expelled through industry competition after the establishment of a socialist market economy. The number of SOEs decreased by 73.7\% from 64,737 in 1998 to 17,052 in 2011. Although the number of SOEs decreased, profits and value-added taxes increased. After SOEs have been expelled through industry competition, they have shifted toward social benefit enterprises and a monopolistic industry. Between 1998 and 2011, value-added taxes and total profits for SOEs increased steadily and although the number of SOEs decreased while these enterprises shifted toward social benefit enterprises and a monopolistic industry, total profits and value-added taxes tripled as the management status improves. 


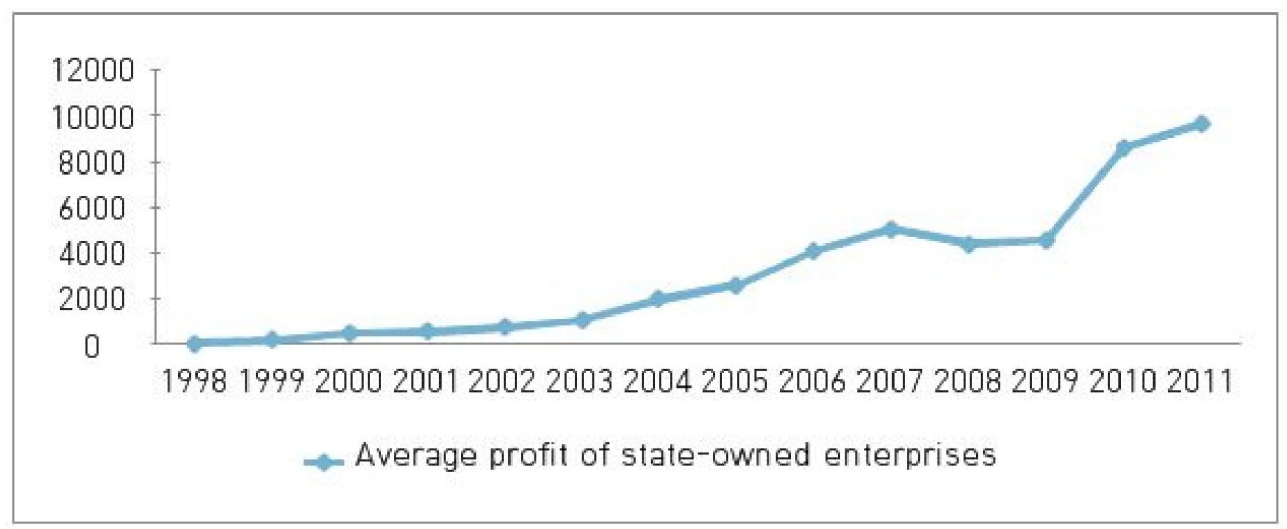

Source: The National Bureau of Statistics of China.

(http://www.stats.gov.cn/tjsj/ndsj/2012/html/N1408e.htm: 14-8 Main Indicators of State-owned and State-holding Industrial Enterprises by Region)

\section{Figure 11.}

Average profit of state-owned enterprises 4 )

Among 8,490 firms in the nonferrous metals industry of a certain size in 2013, 33 belonged on the list of China's top 500 enterprises and most were large SOEs, including Metallurgical Corporation of China Ltd., Jiangxi Copper, Aluminum Corp. of China, Minmetals Corp., Tangling Nonferrous Metals, Shandong Gold, Zijin Mining, Yunnan Copper, Daye Nonferrous, Hunan Nonferrous Metals, West Mining, Nonfemet, Yunnan Tin Group, Zhuzhou Smelter, Chihong Zn\&Ge Co., Ltd. Yunnan Aluminum Co., Ltd., Xiamen Tungsten Co., Ltd. and Jinduicheng Molybdenum Co., Ltd. Since 2000, restructuring and reform efforts for SOEs have gradually reduced their weight in the industry. However, the weight of firms in industries related to energy resources, such as the nonferrous metals industry, still accounts for more than 30\%. As discussed earlier, total profits of Chinese SOEs in 2012 amounted to RMB 1,224 billion and SOEs in the nonferrous metals industry accounted for only $4 \%$ of the total profits. However, SOEs in the the nonferrous metals industry have an opportunity to grow because of sizable efforts to stimulate the economy through industrial development policies carried out since the financial crisis in 2008.

In 2013, the Research and Development Center of the State Council, a think tank of the Chinese government, submitted the " 383 Reform Plan" to the 18th Party Congress to divide the wealth of large SOEs by their region and function. More specifically, despite the

4) Average profit of state - owned enterprises $=$ Number of enterprises $/$ Total profit amount of enterprises 
implementation of reforms to eliminate inefficiencies and surpluses, it has not been easy to achieve large-scale privatization for SOEs because the Chinese government has recently clarified state-owned capital as the basis of socialism. In addition, regional egoism has emerged as a result of local protectionism because the size of each region in China can be a large as a country. Further, local governments provide substantial subsidies to local SOEs to realize GDP goals set by the central government.

According to the "Report of the US-China Economic and Security Review Commission" by the U.S. House of Representatives, Chinese SOEs account for some 50\% of China's GDP, growing rapidly in recent years based on government support in credit financing and technological development. More specifically, the report highlights excessive preferential treatment for SOEs and a need for strengthening transparency by better managing SOE assets and eliminating subsidies by the central government. This is because such subsidies can be a source of export competitiveness and because if markets open when there is no agreement on subsidy reductions in the Korea-China FTA, then Korea's nonferrous metals industry may face unfair trade conditions.

\section{Conclusions}

After the normalization of diplomatic relations between Korea and China, the two countries have become important trading and investment partners and their relationships have matured economically, socially and culturally. From an economic perspective, Korea and China witnessed a 34-fold increase in the size of bilateral trade from $\$ 6.38$ billion in 1992 to $\$ 215.1$ billion and trade proportion also stepped onto a leading position. If the Korea-China FTA is concluded, then trade between the two countries is likely to produce dramatic changes both quantitatively and qualitatively and most industries in the manufacturing sector are likely to be affected by the Korea-China FTA because of the two countries' specialization structures.

However, the potential deepening of concentrated damage should be sufficiently considered in the negotiation process because industries that are expected to see benefits or damage are clearly differentiated. In particular, domestic damage depends on imports of Chinese products, not on benefits expected from the FTA, in the context of nonferrous metals. First, because Korea has no aluminum-refining industry, the country has developed a processing industry selling processed items to domestic and foreign markets based on imports of raw materials. However, import dependence on raw materials and processed materials in the domestic aluminum market has shown a sharply increasing trend because 
China's imports account for a large portion of processed materials. In this regard, China's nonferrous metals industry, which is competitive in terms of both its price and quality, may represent one of the most serious factors threatening Korea under the Korea-China FTA.

Second, China's non-tariff barriers, including export taxes, trade blocs, import restriction measures, anti-dumping policies, safeguards, trade-related investment measures, standard certification systems, services and intellectual property rights, among others, are much higher and more diverse than those of Korea. As discussed earlier, the issue of subsidies for Chinese SOEs, which have played a major role in China's economy, should not be ignored in the process of negotiations for the Korea-China FTA because China has a unique socialist market economy in which the market mechanism is implemented in conjunction with the socialist principle of sharing. China has invested SOE profits as state capital in strategic fields. With the growth of SOEs, it is necessary to pay close attention to the fact that they play a crucial role in supporting various policies of the Chinese government. The more important the industry in China, the more likely it is to receive subsidies from the government and thus more likely it is to see nationalization. In this regard, the nonferrous metals industry is indeed led by the Chinese government, which offers Korean firms in this industry little hope for achieving price competitiveness.

Finally, the issue of SOE management transparency requires closer attention. There are many fields to drive a comprehensive Korea-China FTA high standard as democratization of the board of directors, the establishment of reasonable decision-making systems, the strict evaluation of performance and the arrangement of transparent accounting systems are not systematic and practices, institutions and laws are not transparent. In this regard, Korea must not ignore the fact that China has a socialist market economy and that it has SOEs different from those of Korea in negotiating an FTA with China. In particular, Korea should focus on the suspension of SOE subsidies by the Chinese government and pay close attention to the issue of domestic restriction and transparency in SOE management. Such efforts should help both countries pursue a fair exchange in terms of the nonferrous metals industry and mutual development. 


\section{References}

Kim, Gang Oh (2013). Wisdom to wait till wind of steel/nonferrous metal stops, Hanwha Investment \& Securities.

Kim, Won (2004). International approach of Korean and Chinese accounting standards, a master's thesis of Inha University.

Kim, Young Kwee (2011). Korea FTA policy and Korea-China FTA, 20 year diplomatic relations between Korea and China and economic cooperation prospect in the future, Korea Institute for International Economic Policy.

Kim, Ju Han (2008). Market trend and prospect of iron ore and nonferrous metal, KIET.

Kim, Hang Sung (2013). Responding strategies in Korea-China FTA negotiation in response to change of the international trade environment, Korea Institute for International Economic Policy and Korea International Economic Association policy seminar data.

Sung, Han Kyung (2013). Effects that change of the international trade environment makes on Korea-China FTA and their prospect, Policy seminar data of Korea Institute for International Economic Policy and Korea International Economic Association.

Lee, Moon Young et al (2009). Promotion plan of 10 largest industries in China and analysis of implications for our economy, Korea Institute for Industrial Economics $\&$ Trade.

Lee, Moon Young et al (2011). A research report for 12th 5-year plan direction in China and our measures, pp.587.

Lee, Chun Eui et al (2010). A study for accounting environment in China and accounting transparency international accounting research, 30th edition, pp.203 220.

Lee, Hong Gyu (2013). Is privatization a general trend? Reformation direction of the state-owned enterprises in China and implications, Incheon Development Institute.

Yang, Pyung Sub (2013). Characteristics of trade between Korea and China and driving direction of Korea-China FTA, Policy seminar data of Korea Institute for International Economic Policy and Korea International Economic Association.

Jung, Goon Woo (2013). Effects that Korea-China FTA makes on local manufacturing industry and their countermeasures, Daegu Gyeongbuk Development Institute.

Choi, Moon Sun (2013). Zinc and lead, Outing in 6 years, Korean investment and securities Co., Ltd. 
Jung, Eun Mi et al (2009). Feasibility study for evaluation of nonferrous metal reservation, Korea Institute for Industrial Economics \& Trade.

The Bank of Korea (2013). International economy review Current state and prospect of worldwide nonferrous metal market, 18th edition.

Korea Institute of Public Finance (2010). A research report for reform of the state-owned enterprises in China, Public Institutions Policy Research Center.

Jia Ruoxiang (2011). Driving situation of Korea-China FTA and tasks ahead, Retrospection of 20 year diplomatic relations between Korea and China and economic cooperation prospect in the future $』$, Korea Institute for International Economic Policy.

Northeast Asia Team of KOTRA (2006). Tax risk trend for Korean companies in China and implications.

\section{Chinese References}

朱惠芹. 谢晓嫣,企业经济绩效与社会责任相智性实证分析-我国有色金属行业数据的研究研究 与创新,2011(7上)

本干编辑部,有色金属行业经济形势分析[J], 微型机与应用,2008(04)

陈向阳・赵武叶,2005年我国有色金属工业运行特点分析, 中国金属通报,2006(Z1)

瑞银，中国精铜出口快速增长折射出的思考,UBS Investment Research(2012)

范莉影响中国铅精矿进出口的风险大素分析现代矿业,总第516期

康义,2007年有色金属工业发展报告[J]，中国金属通报,2008(13)

鞠馨・武六具民,2009年我国有色金属产品的外贸分析与展望, 世界有色金属2010(03)

林如海2006, 中国有色金属矿物资源开发现况及展望[J],中国金属通报,2006(35)

刘路妍・袁颖,有色金属资源产业战略联盟: 合作特征“障碍与对策”, 市场周刊( 理论研究), 2010(07)

刘良先·余泽全,2012年中国铇品进出口分析,中国铇业协会,2013(01)

刘良先2010年中国铇品进出口分析,中国铇业协会,2011(01)

刘良先,2009年中国铇品进出口分析,中国铇业,2010(01)

曲永祥,理清经济形势 把脉有色“十二五”一聚焦中国有色金㔉峰会暨上海有色网2010年会,中 国有色金属2011(02) 
屈秋纯, 有色金属矿山转变经济发展方式的途径探讨, 湖南有色金属,2008(03)

王羭垈 al. 中国有色金属产业布局特征及对江苏的启示, 南京社会科学,2009

王华俊,2006年有色金属工业全面增长, 中国有色金属2007(03)

王伟伟·武益民,2011年上牛年中国有色金属产品外贸简析，中国金属通报，2011(31)

芳艳et al. 色矿产资源的整合与优势资源开发, 矿业研究与开发,2008(06)

谢群,“十五”有色金属进出口贸易, 中国有色金属2006(10)

于晨·鞠馨, 有色金属外贸继续向好, 中国金属通报,2011(07)

武益, et al.2010年中国铜产品外贸分析及展望, 资源再生,2011(02)

袁嫄2011年中国铝产品进出口贸易综述 北京安泰科信息开发有限公司,2011

赵武壮,有色产业实现新跨越，中国金属通报，2011(06)

赵武壮,2010年我国有色金属工业运行良好, 资源再生,2011(02)

2010年1 5月有色金属工业运行情况，中国有色治金２010(04)

海䏌信息网,2011年我国铅进出口监测报告,2012(02)

中国有色金属工业协会,2009年我国铜进出口年度报告,2010

中国有色金属工业协会,新中国有色金属工业60年, 中南大学出版㢁什,2009

北京华经纵横咨询有限公司中国铜行业研究报告,2010

国家税务总局䏌于印发，《生产企业出口货物免，抵，退税管理操作规程(试行) 的通知》 (国 税发 [2002] 11号)

《国家税务总局爸于出口货物退(免)税管理有爸问题的通知》(国税发 [2004] 64号)

《国家税务总局兊丁印发《出口货物退免)税管理办法(试行)的通知》(国税发 [2005] 51号)

《国家税务总局䏌于出口货物退(免)税实行有关单证备案管理制度(暂行)的通知》 (国税发 [2005]199号)

《矢于出口货物退(免)税实行有爸单证备案管理制度的补充通知》(国家税务总局国税函 [2006]904号)

\section{Intemet source}

Credit Suisse(2012), "Chinese Aluminum Production: Resilient \& Adapting 2012":

http://www.credit-suisse.com/researchandanalytics

Interview by Zhaoyong (2013), China MINMETAL Vice President: 
http://finance.chinanews.com/ny/2013/06-26/4970266

The China Nonferrous Metals Industry Association Industrial Statistics:

http://www.chinania.org.cn/html/hangyetongji/

The National Bureau of Statistics of China:

http://www.stats.gov.cn/tjsj/ndsj/2012/html/N1408e.htm: 14-8 Main Indicators of Stateowned and State-holding Industrial Enterprises by Region

The China Nonferrous Metals Industry Association Industrial Statistics:

http://www.chinania.org.cn/html/hangyetongji/

The China Nonferrous Metals Industry Association:

http://www.chinania.org.cn/html/hangyetongji/tongji/3.html

China zinc production Report 2001-2010:

http://www.askci.com/data/viewdata187139.html

China zinc production Report 2011:

http://www.100ppi.com/news/detail-20120214- 139846.html

China zinc production of monthly statistics2012:

http://info.1688.com/detail/1115402750.html

The china Nonferrous Metals industry Association. :

http://www.chinania.org.cn/html/hangyetongji/tongji/2013/0130/11201.html2001- 